FACTA UNIVERSITATIS

Series: Economics and Organization Vol. 14, N ${ }^{\mathrm{o}} 2,2017$, pp. 93 - 104

DOI: 10.22190/FUEO1702093P

Original Scientific Paper

\title{
MARKET SIZE AS A DETERMINANT OF THE FOREIGN DIRECT INVESTMENT INFLOWS IN THE WESTERN BALKANS COUNTRIES
}

\author{
UDC 339.1:339.727.22(497-15)
}

\author{
Marija Petrović-Ranđelović, Vesna Janković-Milić, Ivana Kostadinović \\ University of Niš, Faculty of Economics, Serbia
}

\begin{abstract}
Numerous empirical studies confirm that market size is one of the key determinants of foreign direct investment inflows, particularly market-oriented projects of foreign direct investment. Basically, the dominant view is that a larger market of the host country attracts a greater quantum of foreign direct investment. This paper examines the influence of market size, as well as the impact of market growth, trade openness, and population size on the foreign direct investment inflows into the six countries of the Western Balkans region in the period 2007-2015. Multiple regression analysis was applied in examining the impact of these variables on foreign direct investment inflows. The obtained results show that market size, market growth and population size had a significant positive impact, while trade openness had a negative impact on foreign direct investment inflows in the observed countries. Thus, the main findings of this research confirm that market size is an important determinant of the foreign direct investment inflows in the Western Balkans countries.
\end{abstract}

Key words: market size, foreign direct investment, Western Balkans countries

JEL Classification: F21, F23, P20

\section{INTRODUCTION}

The global business environment is increasingly taking the character of multidimensional phenomena influenced by intensive changes in the modern world economy. In the conditions when the intensification of global flows of economic activity are accompanied by increased uncertainty and risk in maximizing profitable business expectations, a growing number of

Received November 2, 2016 / Accepted April 10, 2017

Corresponding author: Marija Petrović-Ranđelović

University of Niš, Faculty of Economics, Serbia

E-mail: mrjpetrovic76@gmail.com 
companies are involved in the processes of internationalization realizing their activities beyond the borders of the national economy.

The significant processes of internationalization of the activities of multinational corporations in the period after the 1980s were followed by an impressive growth of international flows of private capital in the form of foreign direct investment. This statement is confirmed by the fact that global inflows of foreign direct investment increased from 54.396 million in 1980 to $1,762.155$ million in 2015 (UNCTADstat). According to UNCTAD (1991), the explosive growth of foreign direct investment after 1985, is a consequence of the recovery of most economies in the world from the recession of the early 80s, achieving high growth rates in both developed and developing countries and improvement of cross-border mergers and acquisitions activity. In addition, the growth of the service sector in the world economy, supported by the measures of liberalization of regulations on the movement of capital flows in this sector, contributed to the increase of investment activities of multinational corporations. Practical research confirms that foreign direct investment "for two decades had sovereign rule on the global level in the role of promoter of growth and development, especially in developing countries and countries in transition" (Aranđelović \& Petrović-Ranđelović, 2011, p. 143). Despite the fact that developed countries participated with the highest percentage of total inflows of foreign direct investment in the period from 1980 to 2015, an increase in inward foreign direct investment flows towards developing countries from 7,396 million dollars in 1980 to 764,670 million in 2015 is noticeable. In addition, the opening up of markets in the former socialist countries and entering into intensive processes of economic and political reforms in the early $90 \mathrm{~s}$ the interest of multinational corporations to undertake foreign direct investment in these countries sharply increased. Inward foreign direct investment towards the countries in transition increased from only 75 million in 1990 to 34,988 million in 2015 (UNCTADstat).

The growing role of foreign direct investment in the global economy over the past three decades has launched a number of discussions and intensive research in order to determine the relationship between foreign direct investment and economic growth and development. The availability of capital and the level of applied technology is an essential difference between developed countries, on the one hand, and developing countries and countries in transition, on the other hand. The low level of domestic savings certainly represents a far greater development problem for developing countries and countries in transition. In order to compensate for the gap that exists between the volume of domestic savings and the need to finance investment, developing countries and countries in transition are forced to hire additional funds from abroad. The transfer of capital through foreign direct investment represents significant support in their development efforts and catching up with developed countries. Besides, the importance of foreign direct investment in this country lies not only in providing financial support for the establishment of new production capacity and the purchase of equipment, but also in technology transfer and higher forms of organization from a relatively technologically advanced economy. Hence, the fact that the attraction of foreign direct investment has become an important element of the development strategy of developing countries and countries in transition is not surprising.

However, despite the existence of consensus among researchers that foreign direct investment is accompanied by a variety of developmental benefits to the host country, "the major reasons behind foreign investors seeking a country in which to invest and the uneven spatial distribution of FDI across countries are still unanswered questions in both 
the theoretical and the empirical international business literature" (Burcak, 2015, p. 39). Basically, the point is to clarify why companies from some countries decide to locate their production activities in other countries.

The structure of this paper is as follows. After introduction, an overview of the determinants of foreign direct investment is given. The third part of the paper provides a brief review of the empirical literature on market size as a determinant of foreign direct investment inflows. In the fourth part of the paper, is presented the methodology and the information base of research are presented and the initial hypothesis is defined. The fifth part concerns the research results and their discussion. In conclusion, the research results are summarized.

\section{AN OVERVIEW OF THE DETERMINANTS OF FOREIGN DIRECT INVESTMENT}

The fact that foreign direct investment is an extremely complex phenomenon gave rise to an active consideration of all relevant factors that basically encourage the movement of this form of private capital in the international context.

Great debates are led in the scientific community about the determinants of foreign direct investment inflows. Dunning's approach in explaining the limits and models of international production synthetized the OLI paradigm or eclectic theory on foreign direct investment, and is the most reliable theoretical framework for analyzing the determinants of international production. As a comprehensive and internationally accepted concept of foreign direct investment, the OLI paradigm represents a synthesis of the key elements of the three partial theoretical explanations $(\mathrm{O}+\mathrm{L}+\mathrm{I})$ and their combination into a single theory on foreign direct investment. Its importance is reflected in the fact that it implicitly indicates the conditions under which foreign direct investment is realized. These terms do not represent anything other than benefits (ownership advantages of the company, internalization advantages and locational advantages of the host country) which, in themselves, do not represent a direct incentive for the transfer of business activities abroad, but a precondition for achieving adequate profits.

The expansion of cross-border activities of multinational corporations in the period after the second half of the 1980s is the result of imperfections in the market as a dominant feature of international economic relations. In such circumstances, ownership specific advantages are gaining importance. The most common of these are technology or marketing. In this regard, $\mathrm{O}$ (ownership-specific advantages) provides an answer to the question why invest abroad. Multinational companies undertake direct investment abroad on the ground that having one or more specific benefits must clearly outweigh the additional costs which the company is exposed to in its operations in foreign markets. Ownership advantages of the company relate to the possession of a particular product or a particular manufacturing process which other companies do not have the right to use. Also, this includes parts of intangible capital of the company, such as managerial, marketing and entrepreneurial knowledge and skills, organizational skills, and more. Regardless of the form in which they appear, the ownership advantages either increase revenue or minimize the cost of doing business to the extent that is sufficient to neutralize the adverse circumstances in the investment environment of the host country.

However, the ownership-specific advantages alone are not sufficient to explain the expansion of cross-border investment activities of multinational corporations, since the company could exploit them either through licenses or through trade. Therefore, Dunning (2001) analyzed the following elements: 
1. L - locational advantages (locational advantages - the specific advantages of the host country) which provide an answer to the question of where to execute an investment location. The selection of a specific investment location depends not only on the availability of resources, but also on economic, social and political factors, such as the size of the market and its structure, the achieved level of economic development and prospects for future growth, cultural, legal, political and institutional environment and national legislation and policies. Besides, the market potential of the host country of foreign direct investment should offer such a package of locational advantages that will make it a profitable attractive investment location compared to other ways of servicing foreign markets; and

2. I - Internalization advantages provide the answer to the question of which model of entering the foreign markets the company should choose. In the conditions of the existence of market imperfections, companies find it more useful to exploit internally their specific ownership advantages, rather than to sell, or transfer the right to use through the market. Internalization of transactions within the system of multinational corporations is a way not only to use more efficiently the specific ownership advantages, but also a condition for the retention of control over the use of the transferred benefits.

The eclectic theory of foreign direct investment provides a framework for fundamental understanding the motives for undertaking foreign direct investment from the perspective of the investor, as well as the determinants of foreign direct investment inflows. Starting from the fact that in deciding on the operations abroad, multinational corporations have in mind different kinds of motives. According to Dunning we could distinguish the following types of foreign direct investment in terms of their motivation: "(1) Natural-resource seeking foreign direct investment, which aims to gain access to a natural resource not available in the company's home market; (2) Market-seeking foreign direct investment, which aims to gain access to new customers, clients, and export markets; (3) Efficiency-seeking foreign direct investment, which aims to reduce production costs by gaining access to new technologies or competitively priced inputs and labor; (4) Strategic-asset seeking foreign direct investment, which aims to go after strategic assets in a local economy, such as brands, new technologies, or distribution channels" (Hornberger et al., 2011, p. 2).

From the point of the eclectic theory of foreign direct investments, the determinants of foreign direct investment can be classified into two groups: micro determinants or factors on the supply side (company specific), which are specific to each company and involve ownership advantages and internalization advantages, and macro determinants or the factors on the demand side (country specific), which refers to the location advantages of the host country. The importance of individual determinants in determining inward flows of foreign direct investment is largely determined by the country of destination, the sectoral orientation of foreign direct investment, and the model of entry of foreign direct investment in the host country. Let us add that although the role of individual factors in certain situations can be crucial for making investment decisions, yet usually it brings on the basis of observing the interactive operation of factors that shape the investment environment.

Since the attractiveness of a prospective host country of foreign direct investment is conditioned by the location-specific advantages it possesses, it is quite understandable that variations in the distribution of inward foreign direct investment flows globally solely attributed to a number of factors on the demand side, or country specific determinants different in character and practical intensity. According to the literature on foreign direct 
investment, the country specific determinants of inward foreign direct investment flows can be classified for analytical convenience into three categories: a) the policy of the host country, b) economic determinants, and c) business facilities (UNCTAD, 1999).

This study will focus on the economic determinants, with special emphasis on market size as an important economic determinant of inward foreign direct investment flows.

\section{LITERATURE REVIEW}

In modern conditions and trends prevailing in the global economy the question of the amount of the rate of profit as the driving force that encourages owners of private capital to undertake direct investment is becoming less important in comparison to the question of ensuring and maintaining the market. Following the logic of modern economy, it is better to stay in one market in an even lower rate of profit, than to be eliminated from the market. "The former magnetic force high profit rate is now replaced by the large and expansive perspective of the market, former aspirations for higher wages - the desire to avoid large losses. So, the need to conquer new and retain existing markets and the need to establish a long-term fundamentals of international economic cooperation are motivated by the desire for direct foreign investment. They are offered either to provide a long-term investor mainly export finished products or provide long-term and safe imports, mainly raw materials or semi-finished products" (Trlin, 1983, p. 289).

One of the main reasons for undertaking market-seeking foreign direct investment is to avoid the tariff and non-tariff barriers that exist in the country in which it invests directly and to avoid high transaction costs. However, generally speaking, they are taken in order to achieve market access of the host country, as well as achieve a favourable position on it, especially in those where there are good prospects for achieving a dynamic growth in the future, so that the market size of the host country and its growth play a significant role in determining the inward foreign direct investment flows.

According to Chakrabarti (2001), market size has, by far, been the single most widely accepted significant determinant of foreign direct investment flows. Pointing to the importance of market size as the fundamentals of inward flows of foreign direct investment has a long tradition in the literature on foreign direct investment. The market size hypothesis, proposed by Balassa (1966) and later developed by Scaperlanda \& Mauer (1969), supports the idea that "a large market is necessary for efficient utilization of resources and exploitation of economies of scale: as the market-size grows to some critical value, foreign direct investment will start to increase thereafter with its further expansion" (Chakrabarti, 2001, p. 96). By investigating the determinants of US foreign direct investment in the European Economic Community in the period 1958-1968, Scaperlanda \& Mauer (1969) came to the conclusion that the size and growth of the market of the host country play a significant role in the decision on the location of foreign direct investment. The market size hypothesis claims that, due to economies of scale, foreign direct investment will not be taken in any country, if it does not meet the market requirements in terms of size which is necessary for the effective implementation of production technology. When a foreign investor builds production capacity in a given country, the inflow of capital will increase as the demand grows. The role of demand growth is based on the relationship between the total (aggregate) demand and the capital necessary to meet the demand. The hypothesis of growth presupposes the existence of a positive 
relationship between capital inflows and the growth rate of GDP of the host country. By applying simple regression, Scaperlanda and Mauer proved that the inflow of US direct investment, measured on the basis of annual changes in the value position of the European Economic Community, is in accordance with the hypothesis about the size of the market.

The market size hypothesis, as an explanatory variable of inward foreign direct investment flows, is supported by a number of empirical studies on the determinants of inward foreign direct investment flows, in both developed and developing countries, which take GDP per capita as a proxy for market size. Among the earliest research, the study by Bandera \& White (1968) is emphasized. They used pooled data on the United States manufacturing foreign direct investment in seven European economies over the period 1958-1962, and strongly supported the hypothesized dependency of the level of foreign direct investment on the level of national income and the host country. Schmitz \& Bieri (1972) and Lunn (1980) also found a statistically significant effect of market size in determining inward flows of the US foreign direct investment in the EEC, while Kravis \& Lipsey (1982) verified that the host country's market size had a decisive influence on the location decision by the US multinationals in the 1960s. By applying econometric analysis of data on the US manufacturing investment in 24 countries in the period 1954-1975, Nigh (1985) found that the host country GDP per capita was an important factor in determining the inflows of foreign direct investment. The market size hypothesis was confirmed in the study of bilateral flows of direct investment among 6 industrialized countries over the period 1969-1982 (Culem 1998).

By applying econometric analysis of a single equation model using aggregate sectoral data on US multinational investment in 42 countries in the period 1982-1988, Wheeler \& Mody (1992) showed that market size is a more significant factor in determining the inflow of foreign direct investment in developing countries than in industrialized countries. The existence of a strong correlation between foreign direct investment and market size in developing countries as host countries is confirmed in previous studies by Root \& Ahmed (1979), Schneider \& Frey (1985) and Sader (1993).

By applying econometric analysis of a non-linear simultaneous equations model using pooled aggregate data for 62 countries over the period 1975-1978 and for 51 countries over the period 1983-1986, Tsai (1994) observed that a higher per capita GDP is associated with a higher level of inward foreign direct investment. His findings also support the research by Shamsuddin (1994), Billington (1999), and Pistoresi (2000).

"Looking at a set of 30 empirical studies that focus on developing and transition economies, which have been conducted since 2000, some interesting insights are revealed. The studies vary in geographic coverage, with some focusing on transition economies in Eastern Europe and Asia, some on Africa or Latin America only, and some on single countries. Regardless of the geographic focus, the majority of the studies find that the size and growth potential of markets are significantly associated with foreign direct investment inflows" (Hornberger et al., 2011, p. 327).

So, for example, Resmini (2000) investigates the determinants of the European Union foreign direct investment concentrates on the manufacturing sectors in the CEECs at the sectoral level. She found that Central and Eastern European countries with larger populations attract a larger quantum of inward FDI. Bevan \& Estrin (2000) came to similar findings. They pointed out the fact that European transition economies with larger economies tend to attract more foreign direct investment. 
Using panel data for 24 developing countries, Kok \& Ersoy (2009) confirmed in a more recent study that there is a positive relationship between foreign direct investment and market size. Wadhwa \& Reddy (2011) explored the impact of market seeking, efficiency seeking and resource seeking factors of host countries on foreign direct investment inflows of host countries by taking a sample of 10 Asian countries in the time period 1991-2008. Panel regression results show that among market seeking factors, GDP and exports show a significant and positive relationship with foreign direct investment which was also hypothesized.

Gabriel et. al. (2016) examined the influence of market size on foreign direct investment to Nigeria for the period 1970-2011, and found that economy size and population size have a positive and significant effect on foreign direct investment to Nigeria.

\section{METHODOLOGY AND RESEARCH HYPOTHESIS}

The data for this research is collected from the World Development Indicators. The data set covers the period 2007-2015 for the six Western Balkans countries, namely, Albania, Bosnia and Herzegovina, Croatia, Macedonia, Montenegro and Serbia. The dependent variable in this study is the annual FDI net inflow in current US\$. The main reason why we use this dependent variable is because if we use FDI per capita the results may not be comparable, apropos; market size can impact the level of FDI per capita, but not its annual change.

For the purpose of this study we chose four independent variables.

The first independent variable is the Market size, measured by GDP per capita, which "in most empirical works on the determinants of foreign direct investment and has, by far, been the most widely accepted as having a significantly positive impact on foreign direct investment (Chakrabarti, 2001, p. 97). However, it should be noted that some studies have used absolute GDP as an alternative measure. "It has been pointed out that absolute GDP is a relatively poor indicator of market potential for the products of foreign investors, particularly in many developing economies, since it reflects the size of the population rather than income" (Chakrabarti, 2001, p. 98).

Starting from the fact that for "developing and transition countries perhaps more important than market size is market growth potential", (Hornberger et. al., 2011) in this study we introduce another independent variable that refers to Market growth, measured by the GDP growth rate. The introduction of these variables is based on the knowledge that the potential advantages of being a fast growing market are reflected in the realization of the basic motivation for investing - maximizing profits.

The third independent variable is Trade openness. The inclusion of this variable in the study was carried out because in the present conditions of globalization of the world economy, the survival and promotion of an economy is almost unimaginable if it does not follow the model of open and connected with the world economy. International economic cooperation between the countries causes an increasing dependence of countries on foreign trade. The degree of openness of the economy measures the involvement of countries in the international division of labor and the degree of its dependence on other countries. "Openness to "merchandise" trade is the value of merchandise trade (exports plus imports) as a percent of gross domestic product (GDP)" (World Integrated Trade Solution). When the coefficient of trade openness is greater than $50 \%$, it means that one country is heavily dependent on foreign trade. Since by foreign trade the boundaries of the domestic market 
expand, a greater degree of openness of the host country provides an opportunity for foreign investors to realize economies of scale through international markets, rather than just rely on the market of the host country. A greater degree of openness not only contributes to the achievement of economies of scale, but also encourages specialization and efficient absorption of the technology that is transferred through foreign direct investment.

As the fourth explanatory variable in this study, we take Population size. We include this variable in the analysis because, in the development process, population does not occur in a one-sided role of the manufacturers, but also in the role of the factor which, by its purchasing capacity, determines the scale of the internal market.

The objective of this paper is to analyze the impact of market size, along with market growth, trade openness, and population size on the foreign direct investment inflows in the context of the Western Balkans countries. However, the study does not analyze the impact of selected variables on the foreign direct inflow on each country, but on the region as a whole.

In order to investigate the impact of the selected variables on the foreign direct inflows in the Western Balkans countries, the following hypothesis are developed and tested:

H1: There is a statistically significant relationship between market size estimated by the GDP per capita and foreign direct inflows in the region.

$\mathrm{H} 2$ : There is a statistically significant relationship between GDP growth, as a measure of market growth of the observed countries, and the foreign direct investment inflows.

H3: Trade openness does not have a statistically significant impact on the foreign direct investment inflows in the region.

H4: The inflows of foreign direct investment in the Western Balkans countries were statistically significantly determined by population size.

Multiple regression analysis will be applied in order to estimate the influence of the selected variables on the foreign direct investment inflows in the Western Balkans countries.

\section{EMPIRICAL RESULTS AND DISCUSSION}

In connection with the discussion in the previous section, the following variables are included in the multiple regression model:

FDI $\quad-$ Foreign direct investment, net inflows (BoP, current US\$)

GDPp $\quad-$ GDP per capita (current US\$)

GDP growth - annual \%

TRDO - Trade openness (\% of GDP)

POPULATION - total population in observed countries

In the multiple regression model variable, FDI has the character of a dependent variable, while the remaining variables included in the model are treated as independent variables.

This model provides the best value possible to predict the dependent variable based on the value of independent variables if all conditions are met. Based on the size of regression coefficients, it is possible to conclude what the relative impact or importance of each independent variable is if these coefficients are converted into beta coefficient $\beta$. One of the conditions for the use of regression analysis is that there is a linear dependence between variables. It is necessary because the analysis begins by calculating the coefficients of simple correlation (bivariate correlations) for all pairs of variables, all of these calculations require a linear relationship between pairs of variables. 
Table 1 Correlations coefficients

\begin{tabular}{|c|c|c|c|c|c|c|}
\hline & & FDI & GDPr & GDPpc & TRDO & POPULATION \\
\hline \multirow[t]{2}{*}{ FDI } & Pearson Correlation & 1 & -.050 & $.464^{* *}$ & $-.322^{*}$ & $.599^{* *}$ \\
\hline & Sig. (2-tailed) & & .720 & .000 & .019 & .000 \\
\hline \multirow[t]{2}{*}{ GDP growth } & Pearson Correlation & -.050 & 1 & $-.335^{*}$ & .269 & -.221 \\
\hline & Sig. (2-tailed) & .720 & & .013 & $.052 *$ & .108 \\
\hline \multirow[t]{2}{*}{ GDPpc } & Pearson Correlation & $.464^{* *}$ & $-.335^{*}$ & 1 & $-.341^{*}$ & .147 \\
\hline & Sig. (2-tailed) & .000 & .013 & & .012 & .288 \\
\hline \multirow[t]{2}{*}{ TRDO } & Pearson Correlation & $-.322^{*}$ & .269 & $-.341^{*}$ & 1 & -.146 \\
\hline & Sig. (2-tailed) & .019 & .052 & .012 & & .298 \\
\hline \multirow[t]{2}{*}{ POPULATION } & Pearson Correlation & $.599^{* *}$ & -.221 & .147 & -.146 & 1 \\
\hline & Sig. (2-tailed) & .000 & .108 & .288 & .298 & \\
\hline
\end{tabular}

Based on the value of the Pearson correlation coefficient (bivariate correlation), it can be concluded that there is a linear relationship between variables. The conclusion can be made that there is no multicollinearity between the variables included in the model, because the values of correlation coefficients do not exceed 0.5 . Which means that this assumption of multiple linear regression model is fulfilled.

Table 2 shows the values of the coefficient of multiple determination and adjusted coefficient of multiple determination. On the basis of these values, it can be concluded that the selected independent variables explain $57 \%$ of the variability dependent return variables, i.e. FDI.

Table 2 Model Summary ${ }^{\mathrm{b}}$

\begin{tabular}{lccccc}
\hline Model & R & R Square & Adjusted R Square & Std. Error of the Estimate & Durbin-Watson \\
\hline 1 & $.755^{\text {a }}$ & .570 & .534 & 900773997.19 & 1.887 \\
\hline
\end{tabular}

a. Predictors: (Constant), POPULATION, GDPpc, TRDO, GDPr

b. Dependent Variable: FDI

Table 2 shows the realized value of the Durbin-Watson's statistics, which amounts to 1,887 . This test is used to detect the presence of autocorrelation in the residuals, which is characteristic of the time series. For a number of observations at our disposal (54) and the number of independent variables included in the model (4), the upper limit value of the Durbin-Watson statistic is 1.72. Given that the realized value of the Durbin-Watson statistic is greater than this limit value, it can be concluded that there is no correlation between residuals.

Table 3 shows the estimated value of the regression parameters obtained by the OLS (Ordinary Least Squares) method. Based on the obtained values it can be concluded that variable POPULATION (beta coefficient is 0.569 ) has the greatest relative impact on FDI, as well as the highest relative importance in her prediction. Variables GDPpc (significance $<0,001)$ and GDPgrowth $(<0,015$ significance) also have statistically significant impacts on the inflow of FDI. Variable TRDO (beta coefficient is -0.170) has the smallest relative influence and importance in predicting the FDI inflow. The impact of 
this variable is negative, indicating an inverse relationship with FDI. The estimated value of the regression parameter related to this variable is not statistically significant (significance $=0.105$ ), so it can be concluded that the trade openness has no significant impact on the net inflows of foreign direct investment in the observed countries.

Table 3 Regression Coefficients ${ }^{\mathrm{a}}$

\begin{tabular}{|c|c|c|c|c|c|c|}
\hline & \multirow[t]{2}{*}{ Model } & \multicolumn{2}{|c|}{ Unstandardized Coefficients } & \multirow{2}{*}{$\begin{array}{c}\begin{array}{c}\text { Standardized } \\
\text { Coefficients }\end{array} \\
\text { Beta }\end{array}$} & \multirow[t]{2}{*}{$\mathrm{T}$} & \multirow[t]{2}{*}{ Sig. } \\
\hline & & $\mathrm{B}$ & Std. Error & & & \\
\hline \multirow{5}{*}{1} & (Constant) & -228675232.622 & 740664830.473 & & -.309 & .759 \\
\hline & GDPgrowth & 103447572.743 & 40851735.385 & .262 & 2.532 & .015 \\
\hline & GDPpc & 159752.147 & 40915.221 & .408 & 3.904 & .000 \\
\hline & TRDO & -12458245.146 & 7522325.622 & -.170 & -1.656 & .104 \\
\hline & POPULATION & 358.900 & 61.507 & .569 & 5.835 & .000 \\
\hline
\end{tabular}

a. Dependent Variable: FDI

\section{CONCLUSION}

By applying multiple regression analysis, this paper examines the impact of market size, measured using GDP per capita, market growth, measured using GDP growth rate, trade openness, measured using the value of exports plus imports as a percent of gross domestic product GDP and population size, measured using the total population, on the foreign direct investment inflows in the Western Balkans countries in the period 2007-2015.

The key results of this study are consistent with the laid hypothesis. In the above mentioned period, the highest relative impact on the foreign direct investment inflows was recorded for variable population size (beta coefficient is 0.569 ); whereas, statistically significant impact on the foreign direct investment inflows was recorded for market size and market growth (significance $<0,001$ and $<0,015$, respectively). Also, the obtained results hold up the hypothesis that trade openness had no statistically significant impact on the foreign direct investment inflows. Moreover, this variable had a negative impact on the foreign direct investment inflows in the observed countries.

Based on the foregoing, it can be concluded that the results of our study support the findings of other empirical studies on the significant impact of market size on the foreign direct investment inflows. Besides, the obtained results of our study especially emphasise that market size occupies a particularly important place among the determinants of the foreign direct investment inflows and, on that basis, achieves a large influence over the investment decision of multinational corporations in the countries of the Western Balkans.

\section{REFERENCES}

Aranđelović, Z. \& Petrović-Ranđelović, M. (2011). Uticaj države na priliv i efikasnost stranih direktnih investicija [The impact of the state on the inflow and efficiency of foreign direct investment]. Ekonomika preduzeća, 59 (3-4), 143-156.

Balassa, B. (1966). American Direct Investments in the Common Market. Banca Nazionale del Lavoro Quarterly Review, 77, 121-146. 
Bandera, V. N. \& White, J.T. (1968). U.S. direct investments and domestic markets in Europe. Economia Internazionale, 21, 117-133.

Bevan, A. A. \& Estrin, S. (2000). The determinants of foreign direct investment into European transition economies. Journal of Comparative Economics, 32 (2004), 775-787.

Billington, N. (1999). The Location of Foreign Direct Investment: An Empirical Analysis. Applied Economics, 31 , 65-76.

Burcak, P. (2015). Determinants of FDI Into Central and Eastern European Countries: Pull or Push Effect. Eurasian Journal of Economics and Finance, 3(4), 39-47.

Chakrabarti, A. (2001). The Determinants of Foreign Direct Investment: Sensitivity Analyses of Cross-Country Regressions. Kyklos, 54(1), 89-114.

Culem, C. G. (1988). The Locational Determinants of Direct Investments Among Industrialized Countries. European Economic Review, 32, 885-904.

Dunning, J. H. (2001). The Eclectic (OLI) Paradigm of International Production: Past, Present and Future. International Journal of the Economics and Business, 8(2), 176.

Gabriel, O. M., Chigozie, A. O. \& Awara, E. F. (2016). Foreign Direct Investment in Nigeria: Reassessing the Role of Market Size. International Journal of Academic Research in Business and Social Sciences, 6(2), 95-104.

Hornberger, K., Battat, J. \& Kusek, P. (2011). Attracting FDI: How Much Does Investment Climate Matter? The World Bank Group, Financial and Private Sector Development Vice Presidency, Note no. 327.

Kok, R. \& Ersoy, A. B. (2009). Analyses of FDI Determinants in Developing Countries. International Journal of Social Economics, 36(1/2), 105-123.

Kravis, I. B. \& Lipsey, R. E. (1982). The Location of Overseas Production and Production for Ex-port by U. S. Multinational Firms. Journal of International Economics, 12, 201-222.

Lunn, J. (1980). Determinants of U. S. Direct Investment in the E. E. C.: Further Evidence. European Economic Review, 13, 93-101.

Nigh, D. (1985). The Effect of Political Events on United States Direct Foreign Investment: A Pooled Time-series Cross-sectional Analysis. Journal of International Business Studies, 16, 1-17.

Pistoresi, B. (2000). Investimenti Diretti Esteri e Fattori di Localizzazione: L'America Latina e Il Sudest Asiatico. Rivista di Politica Economica, 90, 27-44.

Root, F. R. \& Ahmed, A. A. (1979). Empirical Determinants of Manufacturing Direct Foreign Investment in Developing Countries. Economic Development And Cultural Change, 27(4), 751-767.

Sader, F. (1993). Privatization and Foreign Investment in the Developing World, 1988-1992. World Bank Policy Research Working Paper, 1202.

Scaperlanda, A. E. \& Mauer, L. J. (1969). The Determinants of U.S. Direct Investment in the EEC. American Economic Review, 59, 558-568.

Schmitz, A. \& Bieri, J. (1972). EEC Tariffs and U. S. Direct Investment. European Economic Review, 3, $259-270$.

Schneider, F. \& Frey, B. (1985). Economic and Political Determinants of Foreign Direct Investment. World Development, 13(2), 161-175.

Shamsuddin, A. F. (1994). Economic Determinants of Foreign Direct Investment in Less Developed Countries. The Pakistan Development Review, 33, 41-51.

Trlin, V. (1983). Međunarodna ekonomija - determinante, mehanizmi i politika [International Economics - the determinants, mechanisms and policies]. Sarajevo.

Tsai, P. (1994). Determinants of Foreign Direct Investment and Its Impact on Economic Growth. Journal of Economic Development, 19, 137-163.

UNCTAD (1991). World Investment Report 1991: The Triad in Foreign Direct Investment. New York: United Nations.

UNCTAD (1999). World Investment Report: Trends and Determinants. New York and Geneva: United Nations.

UNCTADstat, http://unctadstat.unctad.org/wds/TableViewer/tableView.aspx, Accessed on: 15.12.2016.

Wadhwa, K. \& Reddy, S. S. (2011). Foreign Direct Investment into Developing Asian Countries: The Role of Market Seeking, Resource Seeking and Efficiency Seeking Factors. International Journal of Business and Management, 6(11), 219-226.

Wheeler, D. \& Mody, A. (1992). International Investment Location Decisions: The Case of U.S. Firms. Journal of International Economics, 33(1-2), 57-76.

World Integrated Trade Solution, http://wits.worldbank.org/openness-to-trade-visualization.html, Accessed on: 15.12.2016. 


\section{VELIČINA TRŽIŠTA KAO DETERMINANTA PRILIVA STRANIH DIREKTNIH INVESTICIJA U ZEMLJAMA ZAPADNOG BALKANA}

Brojna empirijska istraživanja potvrđuju da veličina tržišta predstavlja jednu od ključnih determinanti priliva stranih direktnih investicija, $i$ to naročito tržišno orijentisanih projekata stranih direktnih investicija. U osnovi, dominantno stanovište je da veće tržište zemlje domaćina privlači veći kvantum stranih direktnih investicija. Ovaj rad ispituje uticaj veličine tržišta, kao i uticaj rasta tržišta, trgovinske otvorenosti $i$ veličine stanovništva na priliv stranih direktnih investicija u šest zemalja Zapadnog Balkana u periodu 2007-2015. U ispitivanju uticaja ovih varijabli na priliv stranih direktnih investicija primenjena je višestruka regresiona analiza. Dobijeni rezultati istraživanja pokazuju da su veličina tržišta, rast tržišta $i$ veličina stanovništva imali značajan pozitivan uticaj, dok je trgovinska otvorenost ostvarila negativan uticaj na priliv stranih direktnih investicija u posmatranim zemaljama. Usled toga, osnovni rezultati ovog istraživanja potvrđuju da je veličina tržišta značajna determinanta priliva stranih direktnih investicija u zemljama Zapadnog Balkana.

Ključne reči: veličina tržišta, strane direktne investicije, zemlje Zapadnog Balkana 